\title{
Research Paper \\ Predicting Children's Behavioral Problems based on Maternal Parenting Styles: The Mediating Role of Child Adjustment
}

\author{
Mohammad Kazem Salamat ${ }^{1}$, Masoud Hejazi ${ }^{* 2}$, Zekrollah Morovati ${ }^{3}$, Sirous Isadpanah ${ }^{4}$ \\ 1. Ph.D. Student of Psychology, Zanjan Branch, Islamic Azad University, Zanjan, Iran \\ 2. Assistant Professor, Zanjan Branch, Islamic Azad University, Zanjan, Iran \\ 3. Assistant Professor, Department of Psychology, Faculty of Psychology, Zanjan University, Iran \\ 4. Assistant Professor, Zanjan Branch, Islamic Azad University, Zanjan, Iran
}

Citation: Salamat MK, Hejazi M, Morovati Z, Isadpanah S. Predicting children's behavioral problems based on maternal parenting styles: The mediating role of child adjustment. Quarterly Journal of Child Mental Health. 2019; 6(3): 269-280.

http://dx.doi.org/10.29252/jcmh.6.3.23

\section{A R T I C L E I N F O}

Keywords:

Parenting style, adjustment, behavioral problems

Received: 31 May 2019

Accepted: 11 Sep 2019

Available: 16 Nov 2019

\section{A B S T R A C T}

Background and Purpose: Previous studies have shown that maternal parenting styles play a key role in the child's mental health and that each parenting style has different effects on the psychological well-being of children. Thus, the present study aimed to predict children's behavioral problems based on maternal parenting styles with mediating role of child adjustment.

Method: This research is a correlation study. The statistical population of this study included all preschool students of city in the academic year 2017-2018 (2201 girls and 2688 boys). The sample consisted of 447 (191 girls and 256 boys) preschool students from the mentioned papulation who were selected through multistage cluster sampling. Parenting style inventory (Baumrind 1973), child adjustment questionnaire (1998), and child behavior checklist of the teacher report of ASEBA (2001) were used to collect data in this study. Correlation and path analysis were used to analyze the data. Results: The findings showed that the components of mothers' parenting styles directly affect children's behavioral problems. The results also showed that maternal parenting styles had a direct effect on children's behavioral problems through child adjustment $(\mathrm{P}=0.01)$.

Conclusion: The results of this study showed that the variable of child adjustment in relation to maternal parenting styles with behavioral problems in preschool children plays an undeniable role. Therefore, educating mothers about proper parenting practices and thus improving the levels of the level of child adjustment can be very effective in reducing behavioral problems.

\footnotetext{
* Corresponding author: Masoud Hejazi, Assistant Professor, Zanjan Branch, Islamic Azad University, Zanjan, Iran.

E-mail addresses: Masod1357@yahoo.com
} 


\section{ييشبينى مشكلات رفتارى كودكان بر اساس شيوههاى والدكرى مادران:

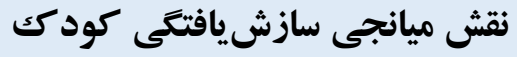

\section{محمد كاظم سلامت'، مسعود حجازى" '، ذكر الله مروتى '، سيروس ايزديناهُ}

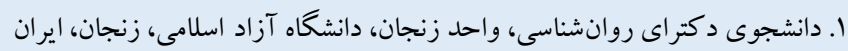

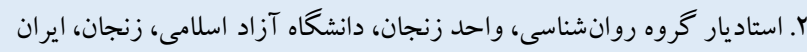

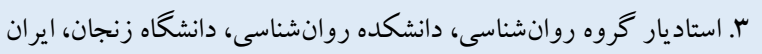

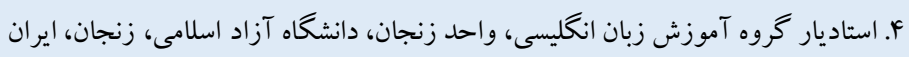

\section{جكيده}

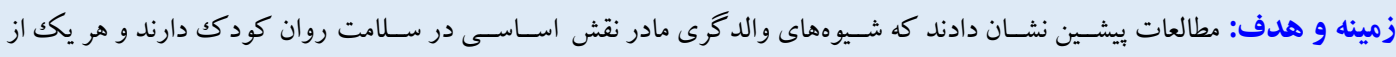

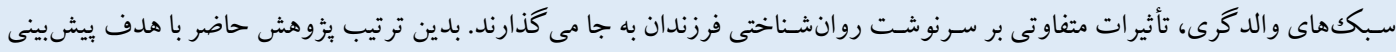

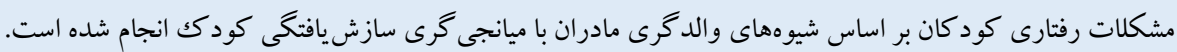

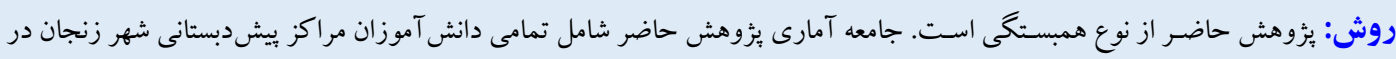

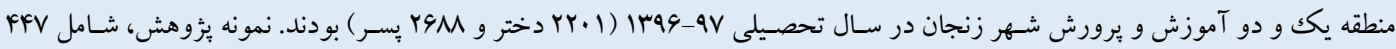

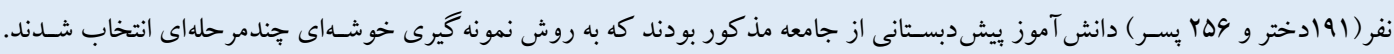

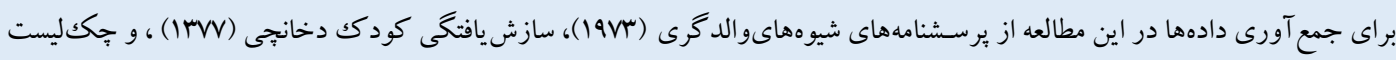

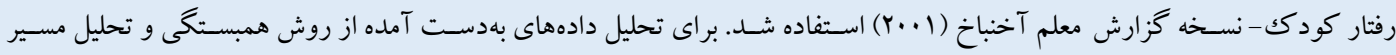
استفاده شد.

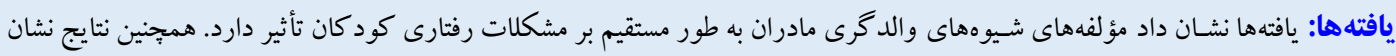

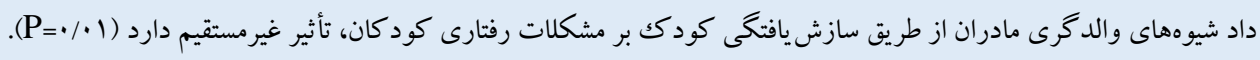

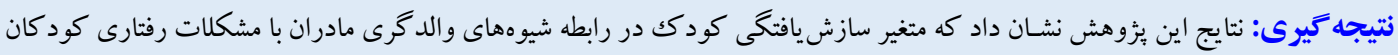

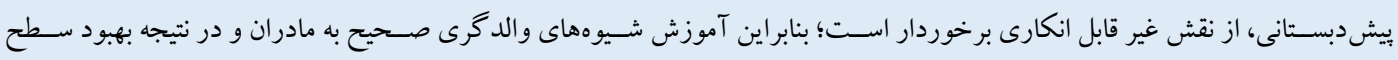

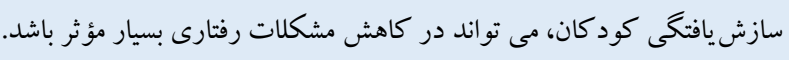

مشخصات مقاله

كليدوازهها:

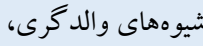

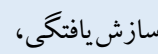
مشكلات رفتارى 
مقلممه

مى گيرد (N). سازش يافتخى مستلزم آن است كه فرد خود را تغيير داده يا اين كـه فعـالـانـه تغييراتى در محيط ايجـاد كنــ (9). عوامـل زيـادى ســازشيـافتكى افراد را تحـت تأثير قرار مىدهد كه يكى از آنها، عامل تربيتى اسـت كه نظريههاى روانيويشـى، رفتار رايى و سـاير نظريههاى روانشناسى، جِكونكى رابطهى اعضاى خانو اده با كودكى و بهويزه نقش مادر رادر اين بين برجسته كردهاند (V)؛ بدين صورت كه هر كاه اختلالى در روابط عاطفى مادر و فرزند ايجاد شـود، امنيت عاطفى كود كك مختل مىشـود و در نتيجه آثار آن در رفتار كودكك به شكل مشكلات رفتارى منعكس مى شـود (9). بر اين اساس خانه، محيط اوليه زندكى فرد است و تـأثير خـانواده و تجـارب اوليـه اجتماعى در محيط خانواده، هنكامى كه يايه هاى الكوى سـازش يافتخى بنا مى شــود، اهميت بسـيارى دارد ( •(1). نتيجـه اين كهكيفيـت زنسدكى كودكك در خـانواده و نوع تعـامـل او بـا والدين، مىتو اند بر سازش يافتكى كودكى (11) و ظهور مشكلات رفتارى

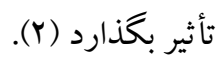

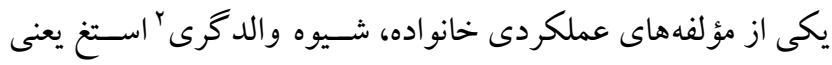
رفتارهاى خاص و هدفمندى كه از طريق آن والدين وظايف خود رادر

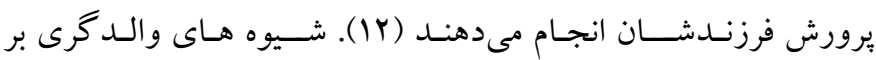
شكل گيرى و تحول شخصيتى و رفتارى كود كان تأثير فراوان و عميقى دارد (Y و r ). بامريند ( •199) در بررسى روابط والدين با كود كان، سه

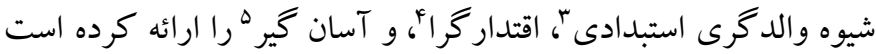
(rا). والدين با شـيوه والدگرى مســبد، صــميميت كم و مهار رفتارى بالايى دارند، رفتارهاى سخت گير انه و انضباطى بر كودكك وضع مى كنند، انتظارات بسـيار بالا از كودكك دارند و مكرر از تنبيه اسـتفاده مى كنند، و ارتبـاط يكك طرفهه با كود كك دارند كه مى تواند بيامد اختلال هاى رفتارى نظير خصــومت، بزهكارى، اضـطراب، شــرارت، خشـونت، و رفتارهاى

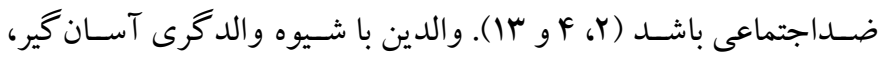
صــميميـت بســــار بـالـا ومهـار ركرى يـايينى در ارتباط با كودكى به كار مى گيرند و بيشـتر همانند يكك دوست با فرزند خود رفتار مى كنند تا يك والـد.آنها همجنين انتظـارات كمى از كودكى دارنـد و از جهـت دهى به

4. Authoritative

5. Permissive
دوران كودكى از مهمترين مراحـل زنســى اســـت كـه در خلـال آن شـخسيت فرد بايهريزى شده و شكل مى گيرد و سالهاى ابتدايى تحول در خانواده، نقش اسـاسى در رفتارها و سازش يافتكى كود كان در آينده دارنــ (1). كود كـان بـه عنوان يكى از كروههاى ســنى آســيبـيذير در معرض انواع مشــكلات روانشــناختى قرار دارند (Y). كود كان به دليل اينكه شــديداً از نظر توانمندى هاى جســمانى و ذهنى نارس هســتند و به

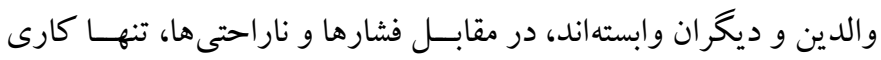
كـهـ مى تو انند بكنند بــروز مشـكلات رفتـارى است. مشكلات رفتارى، آن دسـته از رفتارهايى هستند كه با وجود يايين نبودن بهره هوشى، تعادل روانى، و رفتارى فرد از جمعيت عموم جامعه، از نظر شــدت، مداومت و بروز در مكانهاى مختلف به كونهاى هسـتند كه بر عملكرد تحصـيلى و رفتارى فرد اختلال ايجاد كرده و موجب كاهش ميزان كارايى شـود (r). رفتـار كــــودك در واقع، زبــان كويــاى اوست. هرجهه كـــودك در ار تبـــاط با ديخــــــان و بيان احساسات و تأمين نيازهاى خود مشــــلـات بيشـترى داشـته باشد، مشكلات روانى و رفتارى بيشتــــرى خواهد داشت (F)؛ بنابر اين هر نــــوع رفتــــار غيرعادى كودك يـ مســائل و اختلالات رفتارى او راعـلاوه بر خصيصههاى مربـوط به دورههاى تحولى، مى توان

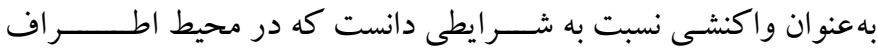
كــــودك بهويزه خانواده وجـــود دارد (Y). بر اين اساس آسيب يذيرى كودكـان در اين ســنين از يـكك ســو تحـت تـأثير فراينــ فعال تحول و مقتضـيات خاص مراحل آن، و از سـوى ديخر تحت تأثير مهار شــرايط محيطى و موقعيتى كودكك در خانواده توسط بزر گسالان است (ه).

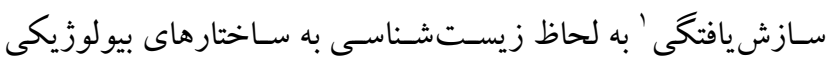
اشـاره دارد كه زنده ماندن انواع را تسهيل مى كند و نه تنها انسانها، بلكه حيوانات و نباتات رانيز شامل مىشود (9). در روانشناسى، سازشيافتكى فرايندى كموبيش آكاهانه فرض مىشـود كه بر پيايه آن فرد با محيط اجتماعى، طبيعى يا فرهنگى انطباق مى يابد (V). اين فرايند همجينين شامل انطبـاق بـا تغييرات، جســتجوى مكـان تازه و موقعيت ها، ترميم هيجانات منفى، و ابراز احساسات مثبت در زمان واكنش متقابل با ديخران را در بر

1. Adjustment

2. Parenting

3. Authoritarian 
رودريكز، و وانســنكيس، ســونيس، ســونيز و اوليوا (·r) نشــان داد كه

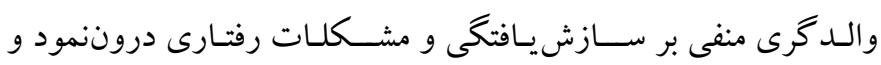

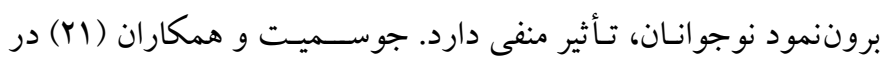

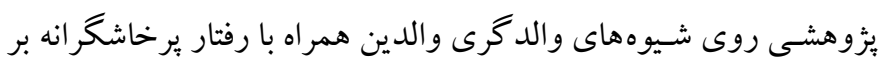

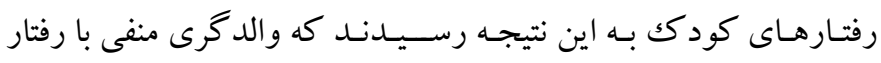

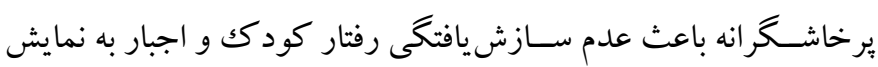

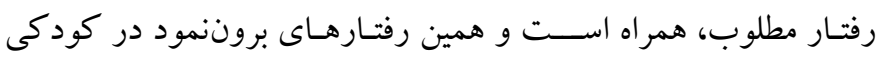

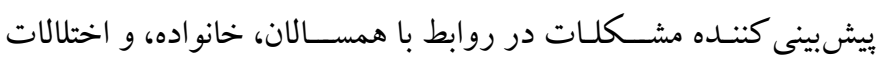
رفتارى در نوجوانى اسـت. در همين راسـتا كائول، كانتنمبر گك و آنانت

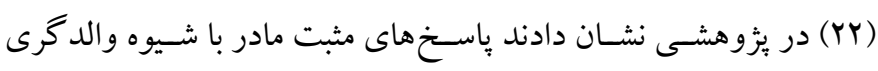

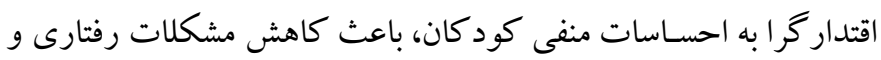

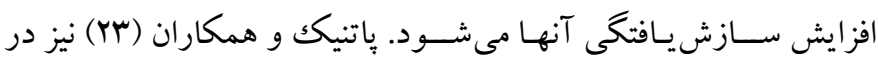
بررسى بر روى شيوه والدگرى مادران به اين يافته رسيدند مادرانى كه با باني

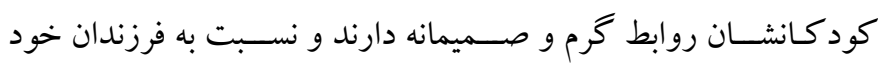

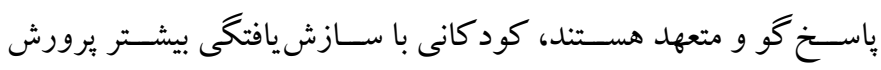
مى دهند و فرزندشـان مشـكلات رفتارى تهاجمى كمترى نشـان مى دهند.

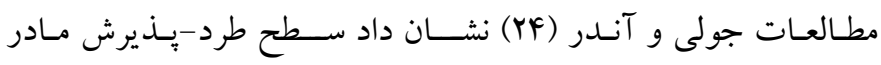
يسيش بينى كنتسده قوى مشـكلـات رفتـارى درونتمود و بروننمود و

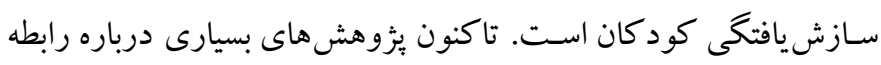

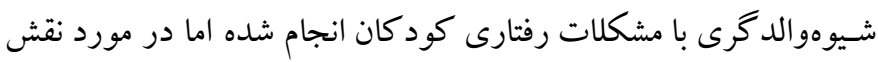

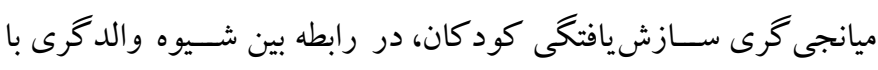

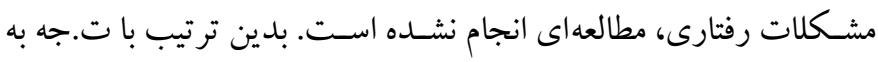

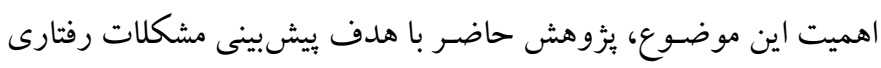

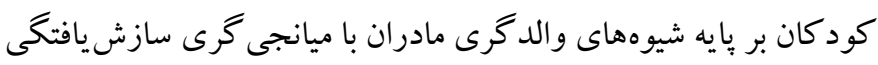

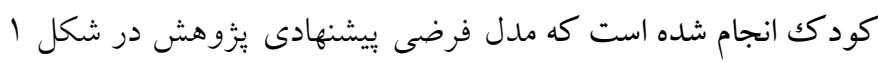
ترسيم شده است.
رفتـار كود كك يرهيز مى كننــ (9). بيـامـدهـاى آســان گيرى اين والدين

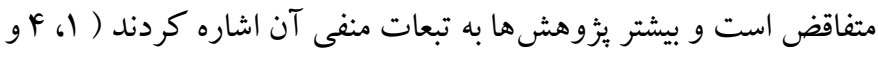

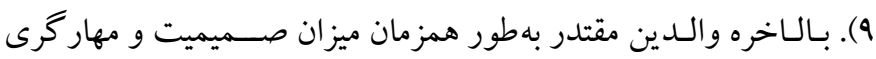
بالايى را در تربيـت فرزنـد خود به كار مى گيرند، عقلانى و منطقى رفتار

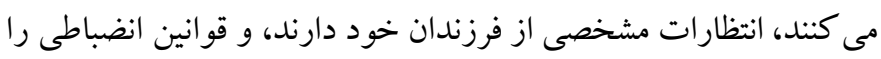

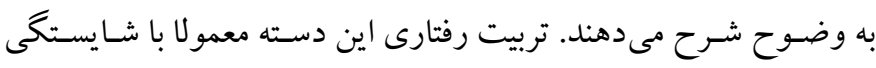

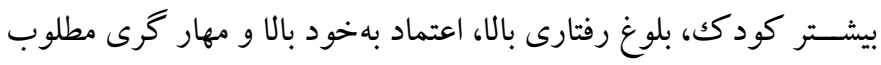

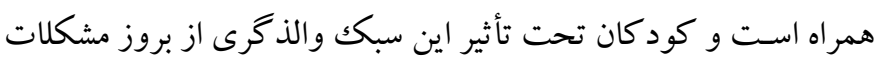

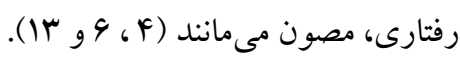

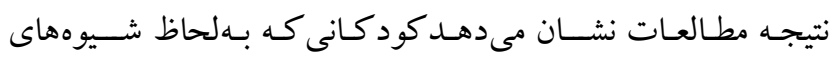

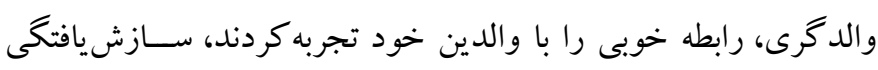

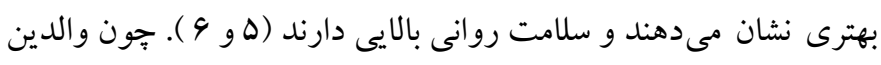

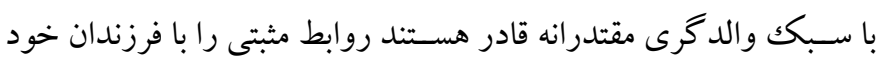
حفظ كنند، و سـازش يافتكى فرزندان خود را تسهـيل مى كنند؛ در مقابل

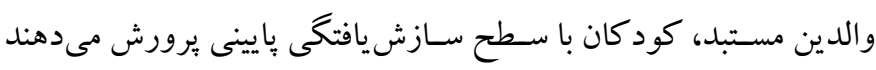

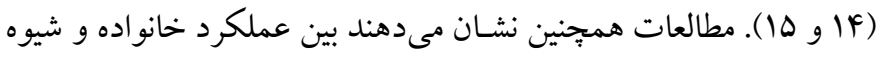

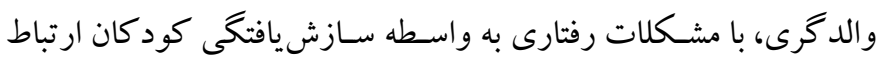

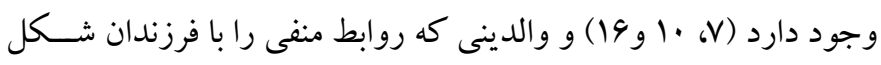

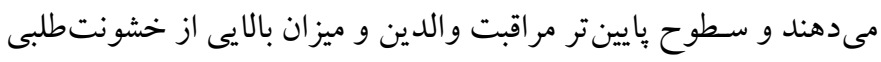

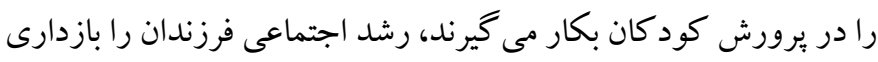

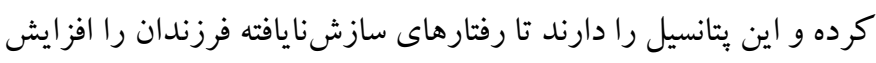

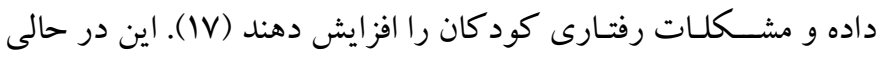

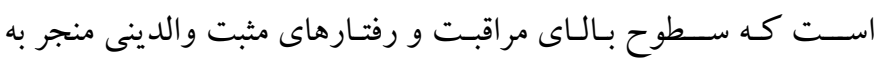
سازش يافتكى بالاتر كودك در آينده و كاهش مشكلات رفتارى مى شود

مطالعات سـونيس و وانستين كيست (19)، اثر زيانبار والدگرى منفى

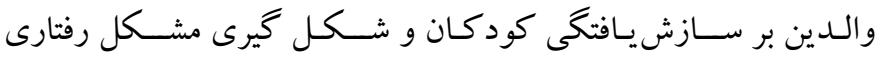

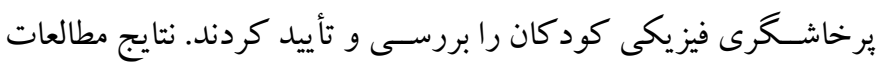




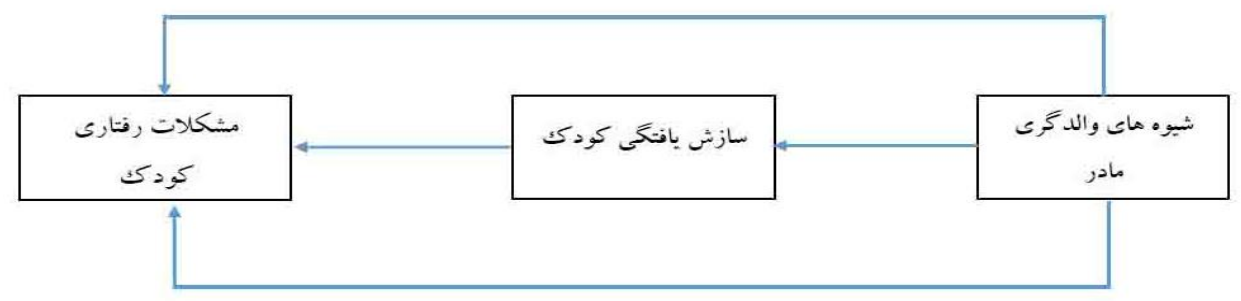

شكل ا: مدل فرضى بيشنهادى يزوهش

كنار گذاشـته شــند. دادههاى جمعيت شناختى از كل نمونه نشان داد كه

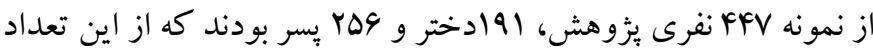

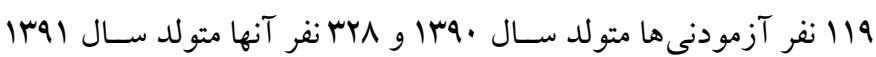

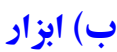

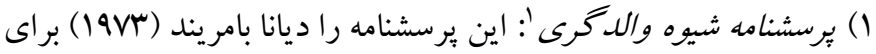
سنجش سه شيوه والدگرى سهل گير انه، مستبدانه، و مقتدرانه تدوين كرده

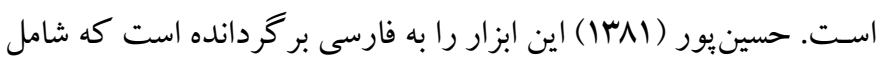
• ب كويه سوم شخص است كه · اعبارت آن به شيوه مستبدانه، · إخويه

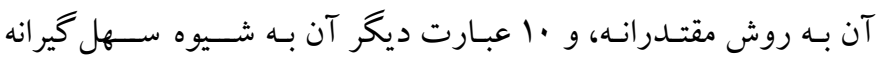

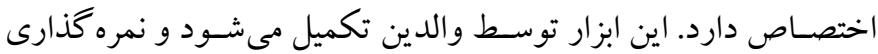
آزمون بر اسـاس طيف بنج گزينهاى ليكرت بودهه و با جمع آورى نمرات

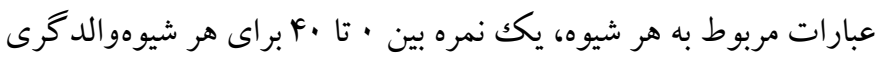

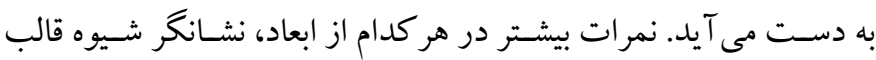
والدگرى آن فرد است. در يثوهشى كه توسط اسفنديارى (ITVF) انجام شد اعتبار آزمون بر روى نمونهاى از مادران جمعيت مورد مطالعه به شيوه

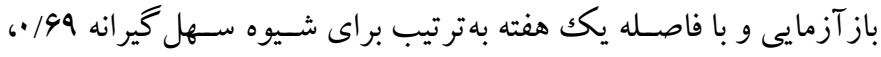

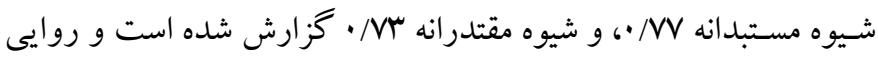
محتو ايى يرسـشـنامه نيز توســ · انفر از صـاحبنظران روانشـناسى و

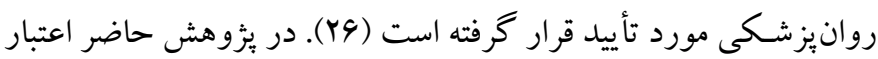
بهدست آمده براى خردهمقياسهاى سهل گيرانه 9//، استبدادى 9// •، و

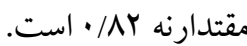

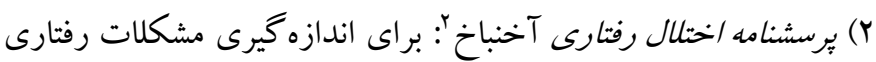

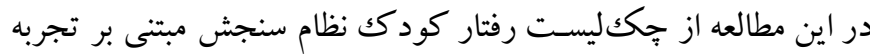

الف) طرح هزوهش و شـر كت كنند كان: اين يزوهش بر اسـاس روش

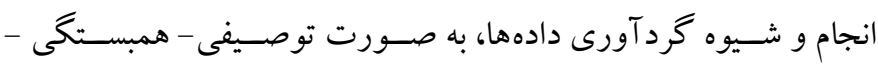

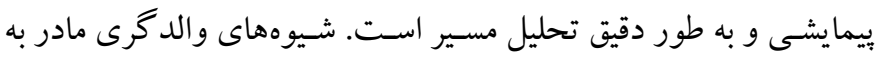

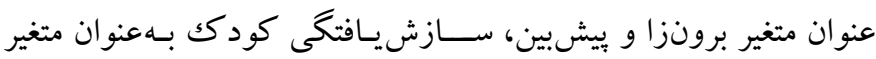

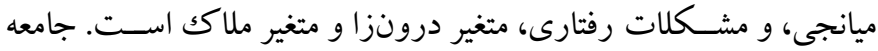

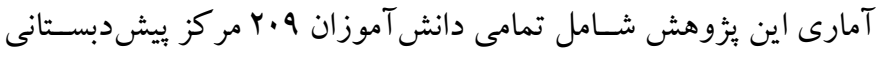

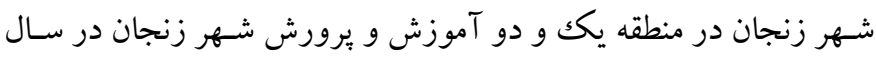
تحصـيلى

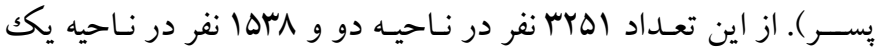

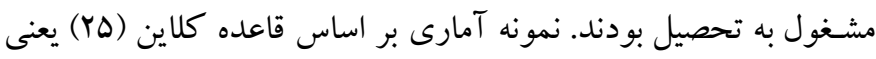

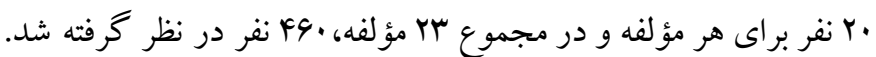

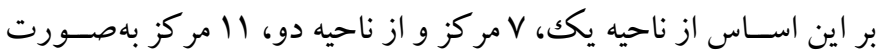

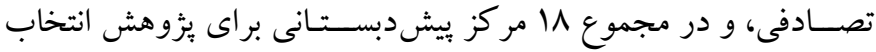

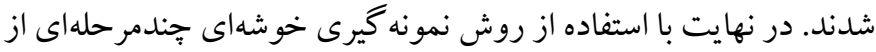
هر 11 مركز ييشدبسـتـانى، يـك كلـاس انتخاب و تمامى كود كان آن

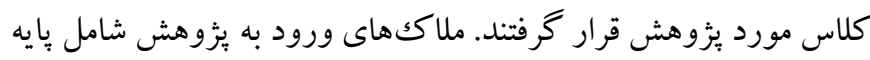

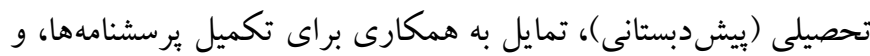

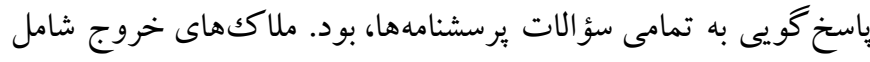

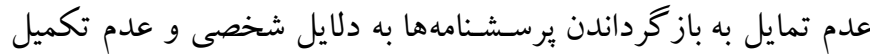

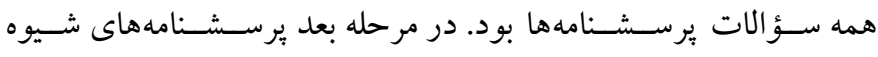

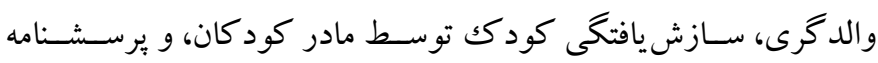
اختلال رفتارى توسط مربيان بيش دبستانى براى تكك تكك كود كان تكميل

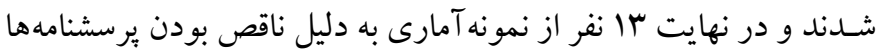


نمره • تا مامى تواند به هر يكك از سوالها تعلق بخيرد و حداقل و حداكثر

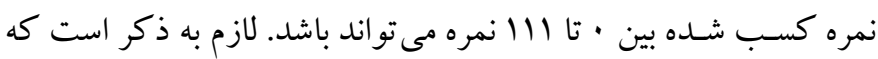

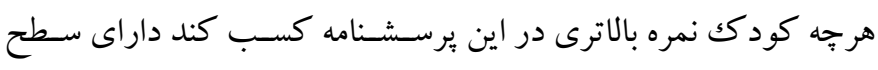

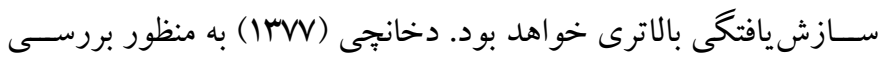

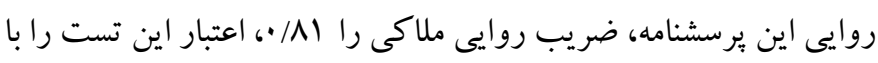

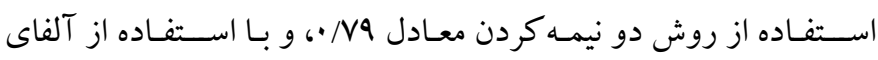

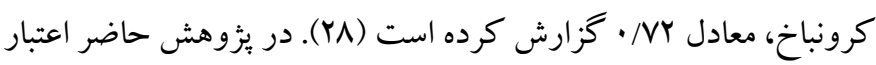

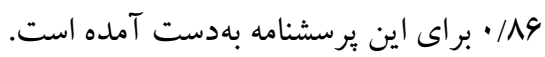

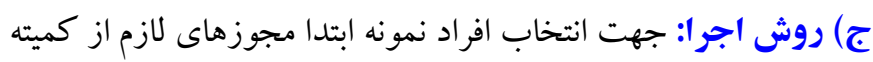

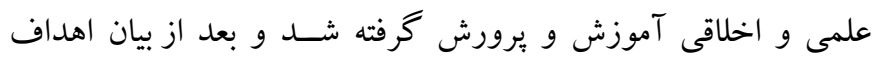
يزٔوهش و رعـايت ملاحظات اخلاقى، از والدين كود كان و مربيان مراكز

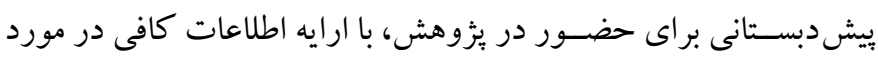

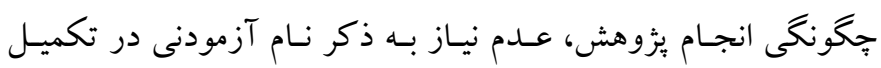
ير سـشنامه ها، اطمينانبخشى جهت محر مانه ماندن اطلاعات بهدست آمده،

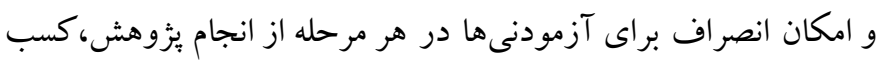

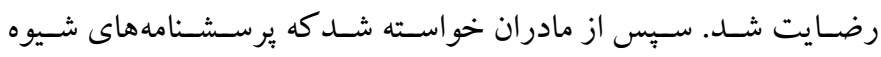
والدكرى و سـازش يافتكى كود كك را تكميل كنند و همجنين از مربيان

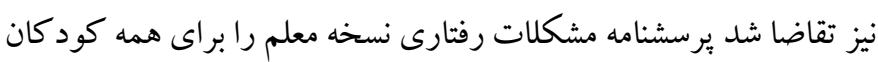

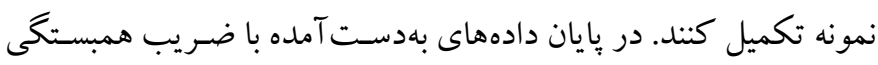

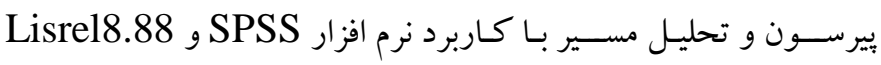
بررسى و تحليل شدهاند.

يافتهها

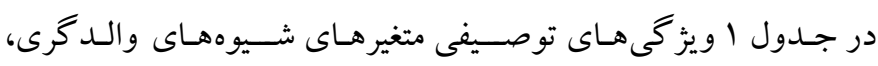

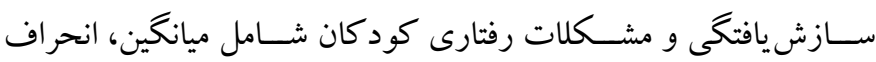
استاندارد، جولكى و كشيدگى متغيرهاى بثزوهش آورده شده است.

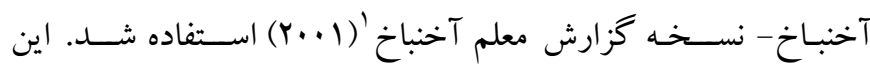

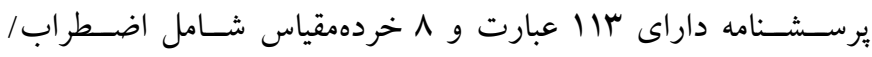

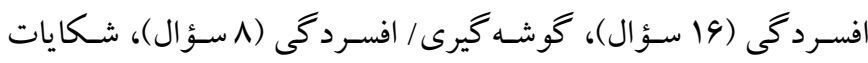

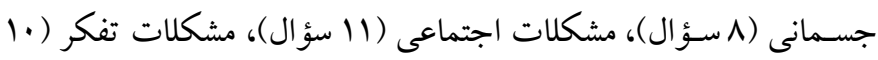
سؤ ال)، مشكلات توجه (צr سؤال)، رفتار قانونشكنى (Y اسؤال)، رفتار

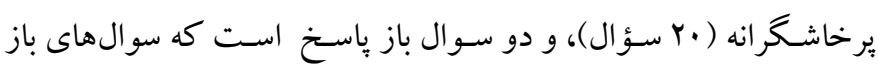

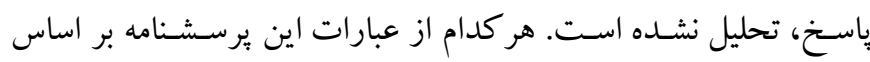

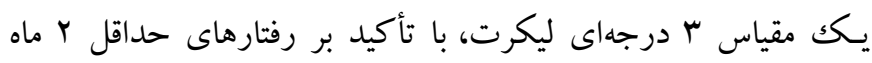

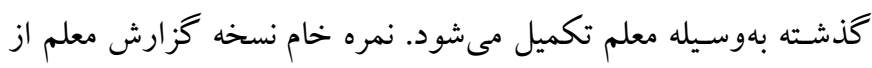
طريق جمع سؤالات در هر خردهمقياس به دست مى آيد. يس از محاسبه

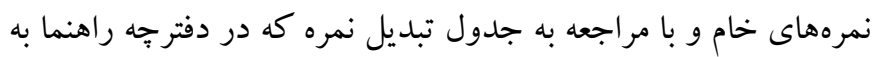

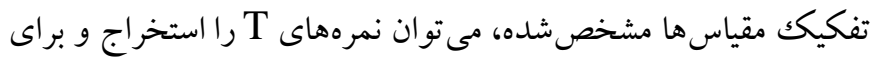

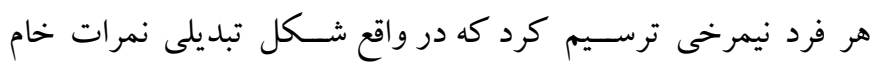

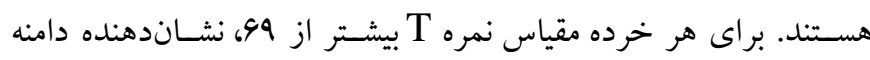

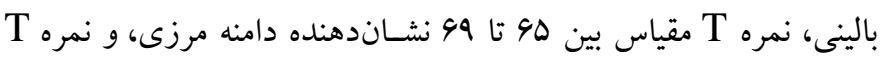
كمتر از 90 مبين دامنه نرمال اسـت. ضـريب كلى اعتبار اين آزمون با فيا

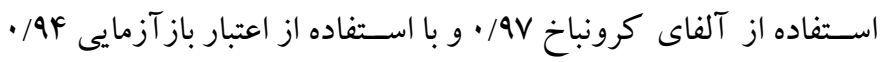
كزارش شده است. اعتبار و روايى اين آزمون براى اندازه گيرى مشكلات

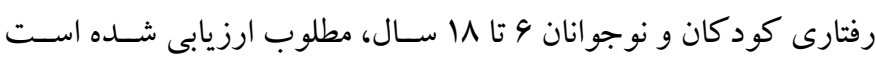

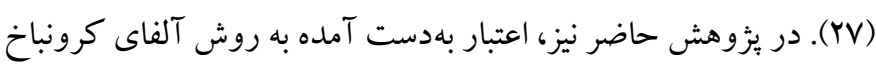

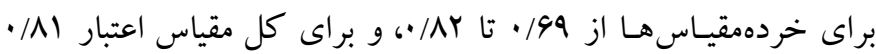
بهدست آمده است.

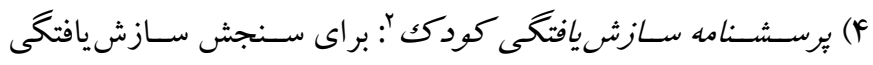

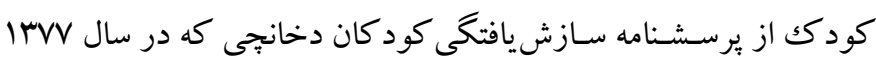

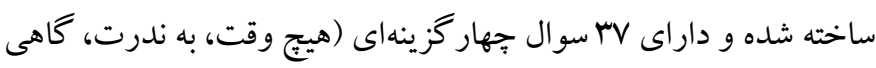

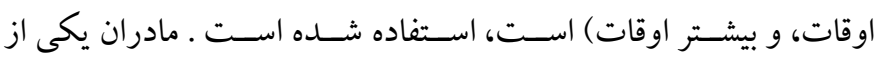
كزينه هايى كه با رفتار فرزندشـان بيشتر مطابقت دارد را را انتخاب مى كنئد. 
جدول 1: نتايج توصيفى متغيرهاى يزوهش

\begin{tabular}{|c|c|c|c|c|}
\hline كشيدىى & جولكى & انحراف استاندارد & ميانكين & متغير \\
\hline$\cdot / \mu \Lambda$ & $-\cdot / 14$ & $9 / 90$ & ri/ro & شيوه اقتدارگرا \\
\hline r &.$- / .9$ & $r / \Lambda \Delta$ & $r r / \Delta \Lambda$ & شيوه آسان گير \\
\hline . & $-\cdot / \cdot v$ & $V / 90$ & $r Q / 9 Y$ & شيوه استبدادى \\
\hline$\cdot / r q$ &.$- / .9$ & $10 / 90$ & $V \Delta / q F$ & سازش يافتخى \\
\hline$\cdot / 41$ &.$- / .9$ & $r N / F$ & mI/FA & مشكلات رفتارى \\
\hline
\end{tabular}

دادههـا مفروضسههـاى بهنجارى يككتغيرى، بهنجارى خندمتغيرى، و

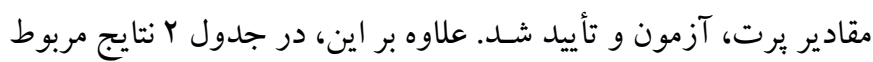

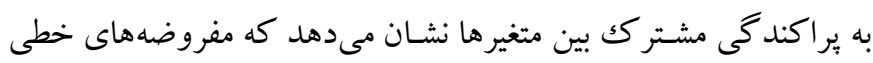
بودن و عدم همخطى جند كانه رعايت شده است.
در مدليابى على، توزيع متغيرها بايد نرمال باشــــ و قدر مطلق

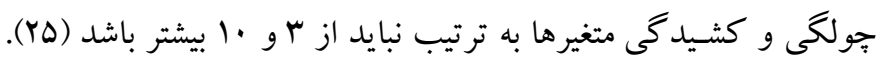
با توجه به جدول ا قدر مطلق جولكى و كشيدگى تمامى متغيرها كمتر

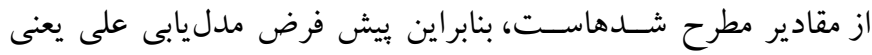
نرمال بودن تككمتغيرى برقرار اسـت. در مطالعه حاضـر، قبل از تحليل

جدول r : ماتريس همبستغى متغيرهاى اصلى بروهش

\begin{tabular}{|c|c|c|c|c|c|}
\hline 0 & $\varepsilon$ & $r$ & r & 1 & متغير \\
\hline & & & & 1 & اقتداركرا \\
\hline & & & 1 & $-\cdot / 10 \%$ & آسانگير \\
\hline & & 1 & $-\cdot / \Gamma \Delta$ 米莎 & 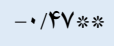 & استبدادى \\
\hline & 1 & $-\cdot / Y V$ 䄅* & $-\cdot / 1 \Delta *$ & $\cdot / Y F_{\text {䄅䊅 }}$ & سازش يافتگى \\
\hline 1 & $-\cdot / \Gamma F_{\text {米米 }}$ & $\cdot / Y \Lambda$ 兴粠 & $\cdot / r$ & $-\cdot / Y \mid$ 紫米 & مشكلات رفتارى \\
\hline
\end{tabular}

$* * \mathrm{P}<\cdot / \cdot 1$

مرديا' استفاده شـــ اين عدد در يزووهش حاضر سو/ أبهدست آمد كه كمتر از عدد ها اسـت كه از طريق فرمول p(p+2) محاسبه شده است. در اين فرمول p مسـاوى اسـت با تعداد متغيرهاى مشـاهده شده كه در

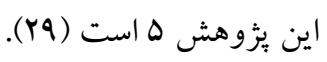

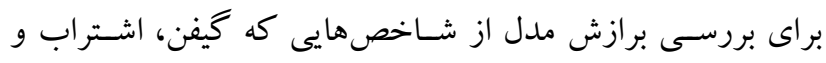

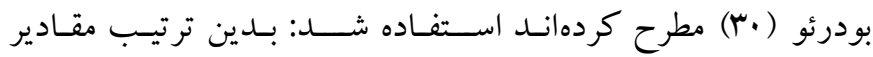

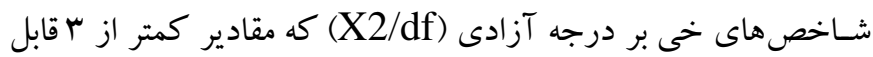

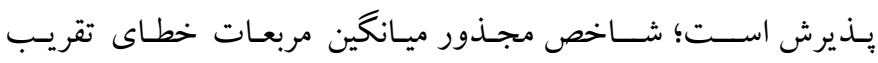

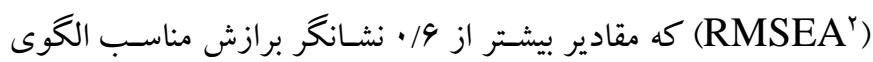

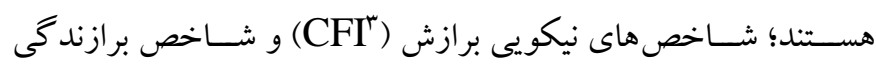

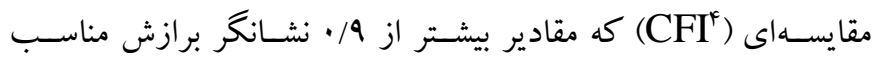

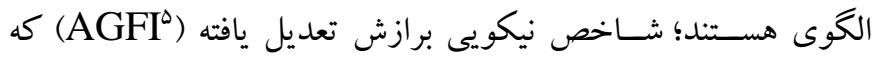

4. Comparative fit index

5. Adjusted Goodness of Fit Index
طبق اطلاعات جدول r رابطه بين مشـكلات رفتارى كود كان با شـيوه

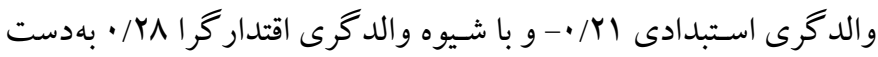
آمده اســت كه هر ســه در ســح كمتر از 1 • • معنى دار اسـت. رابطه

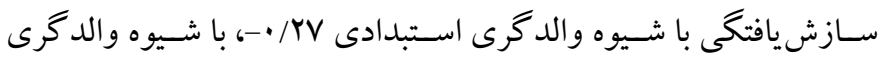

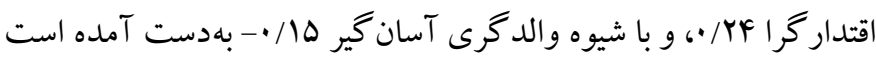
كه هر سـه در سطح كمتر از 1 •/ • معنىدار است. همجنين رابطه سازش يافتكى با مشكلات رفتارى در كود كان بيشدبستانى نيز منفى معنى دار به مقدار FF/ •-- بهدست آمده است. از روش بيشــينه احتمال براى آزمون الكوى نظرى يثوهش و برازش آن با دادههاى كرد آورى شده استفاده شد. استفاده از اين روش نيـازمند نرمال بودن جندمتغيره متغيرها اســت. در اين بزوهش براى بررسسى نرمال بودن جندمتغيره از ضـريب كشـيد كى اسـتاندارد شـده

1.Mardia's normalized multivariate kurtosis value

2. Root Mean Square Error of Approximation

3. Goodness of fit index 
با انجام تحليل مسير، شسيوه والدگرى آسـانگير از مدل اوليه به دليل

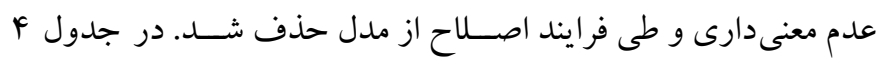

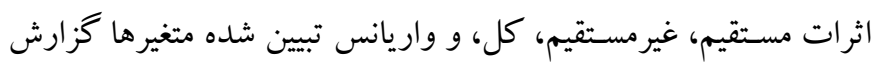

شده است.
مقادير بيشتر از ^/• قابل قبول هستند؛ و شاخص برازش ايجاز (PNFI')

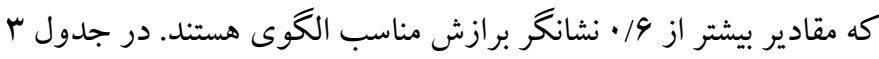

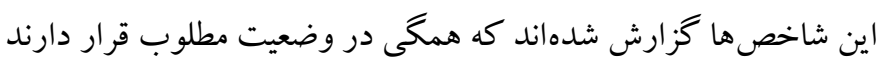

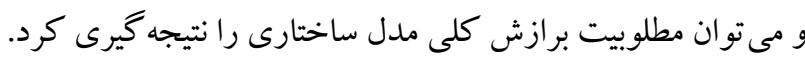

\begin{tabular}{|c|c|c|c|c|c|}
\hline \multicolumn{6}{|c|}{ جدول r : شاخصهاى برازندكى } \\
\hline & AGFI & CFI & GFI & RMSEA & $\mathrm{X} 2 / \mathrm{df}$ \\
\hline
\end{tabular}

جدول ع: اثرات مستقيم، غير مستقيه، كل و واريانس تبيين شده متغيرها

\begin{tabular}{|c|c|c|c|c|}
\hline واريانس تبيين شده & اثر كل & اثر غير مستقيم & اثر مستقيم & متغير \\
\hline \multirow[t]{4}{*}{$\cdot / 1 \Lambda$} & & & & به روى مشكلات رفتارى \\
\hline & & - & $-\cdot / 19$ \%䓠 & سازش يافتكى كودكى \\
\hline & $\cdot / 41$ 些䄅 & $\cdot /|F|$ 类米 & - & والدكرى استبدادى \\
\hline & $-\cdot / \Upsilon \wedge$ 漛粪 & $-\cdot / \Upsilon \wedge$ 类粪 & - & والدگرى اقتدارگرا \\
\hline \multirow[t]{3}{*}{$\cdot / \wedge$} & & & & به روى سازش يافتكى \\
\hline & $-\cdot / 19_{\text {䄅䄅 }}$ & - & $-\cdot / 19 \%$ & والدگرى استبدادى \\
\hline &.$/ .9 \%$ & - &.$/ .9 \%$ & والدگرى اقتدارگرا \\
\hline
\end{tabular}

$* * \mathrm{P}<\cdot / \cdot 1$

منفى و معنىدار است. با توجه به اينكه اين اثرات از طريق سازش يافتخى با توجه به جدول \& ا ثر مستقيم سازش يافتكى كود كك روى مشكلات

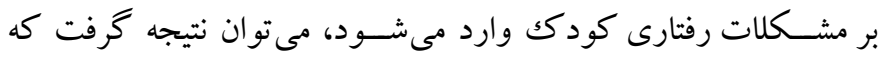

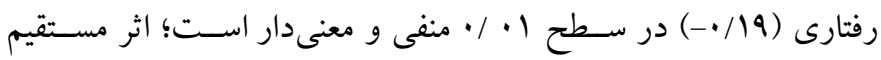

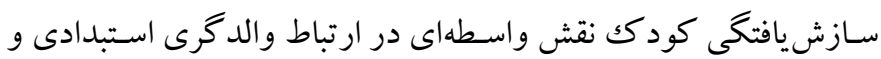

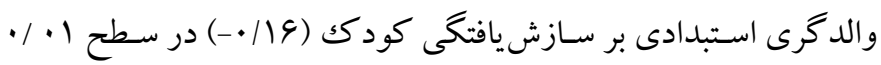

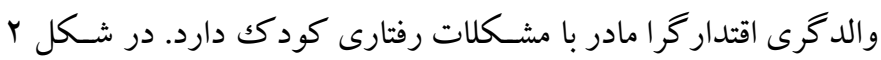

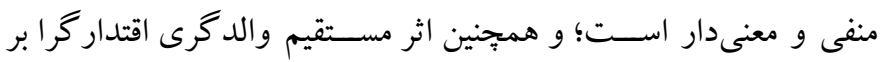

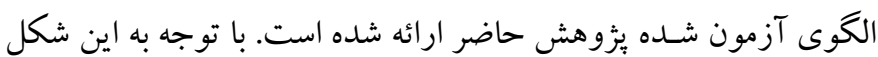

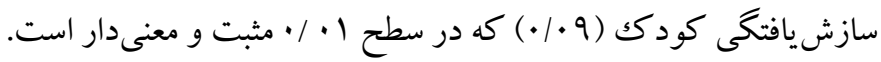
سـازش يافتكى \1 درصـد از واريانس مشكلات رفتارى كود كك را تبيين مطابق جدول \& اثر غير مسـتقيم والدگرى اســبدادى (أF/•) بر

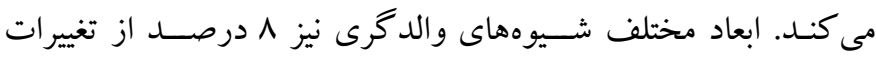

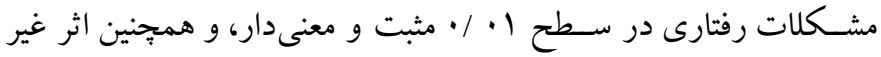
سازش يافتخى را يبش بينى مى كند.

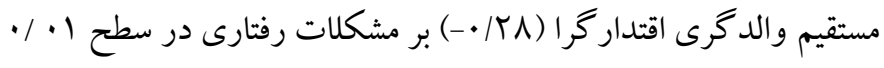

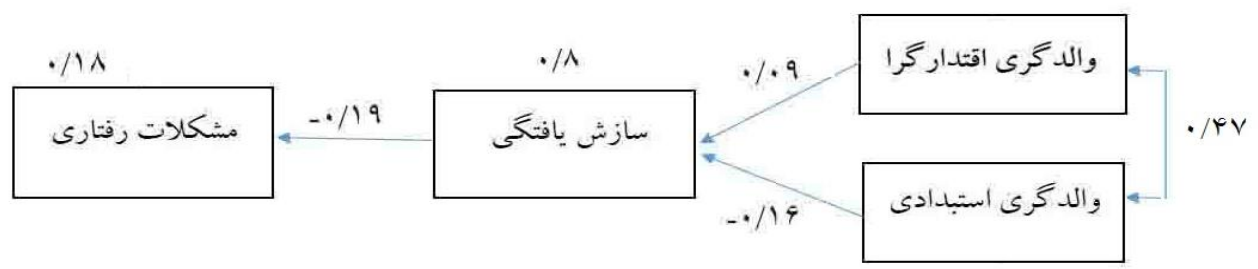

شكل r: ضريب برآوردى مدل ساختارى يزوهش (بر آورد استاندارد) 
فرزنـدان احترام مى گحذارنـــ (F و 9)، انتظـارات معقولى از فرزندان خود

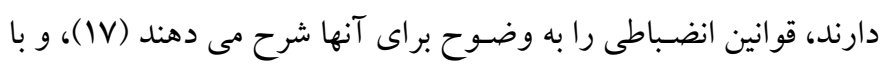

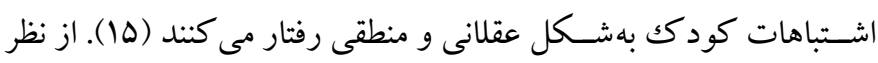

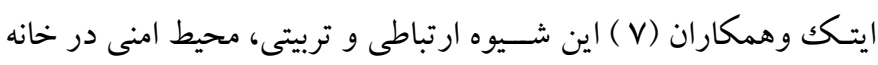

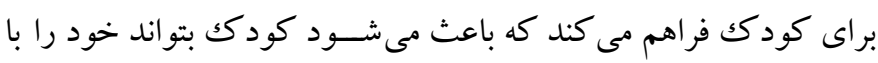

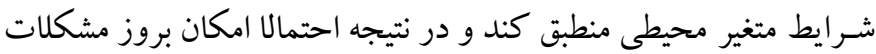
رفتارى در او به حداقل مىرسد.

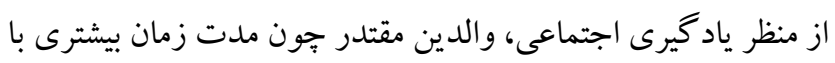

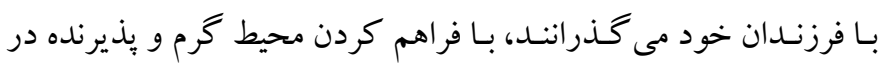

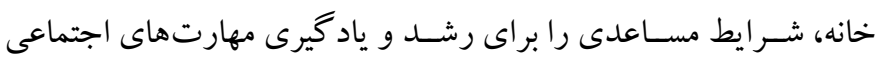

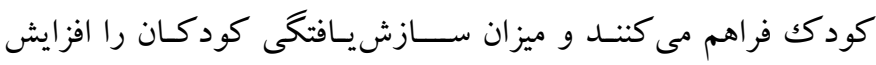

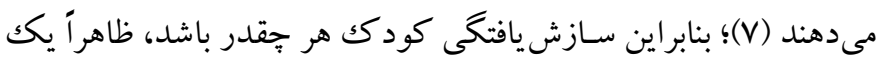

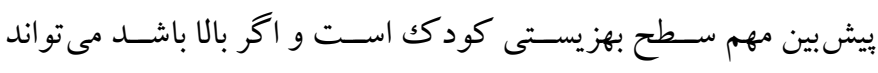

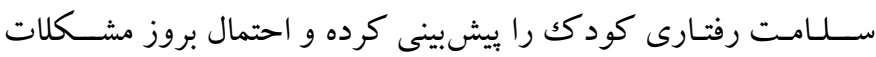

رفتارى را كاهش دهد (1).

نتايج اين مطالعه همجنين همسو با بثزوهشهايى رهاس است كه نشان دادند

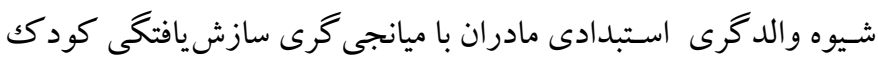

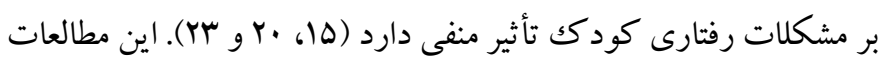

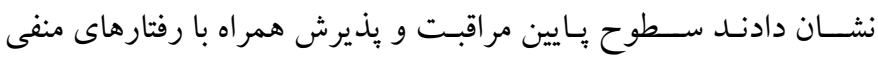
والدينى به سازش يافتكى بايين تر كود كك منجر مى شود كه بيش بيش بينى كننده

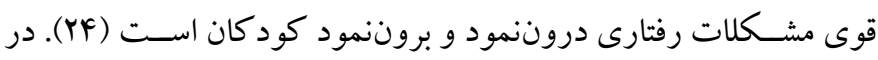

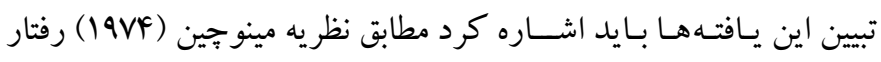
اعضاى يكك خانواده تابعى از رفتار ساير اعضاء خانو اده (والدين) است و و

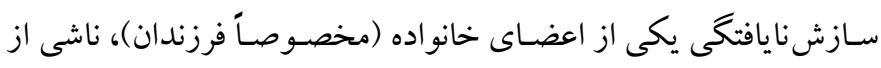

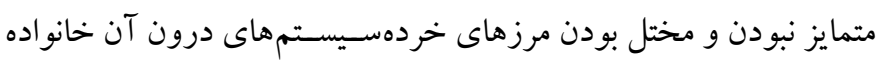

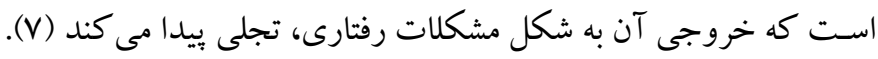

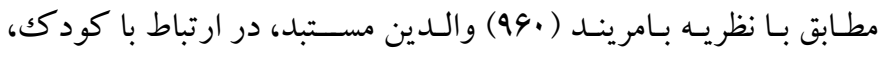

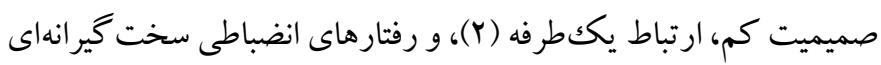

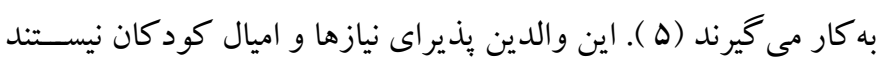

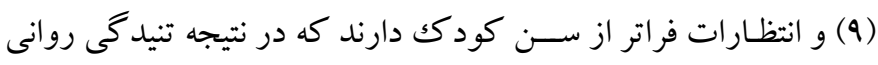

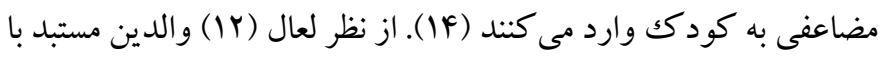

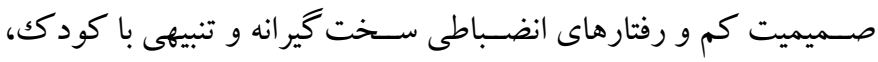

\section{بحث و نتيجه كيرى}

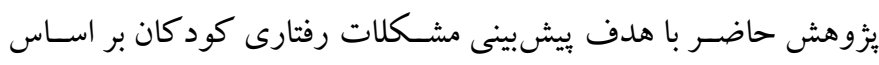

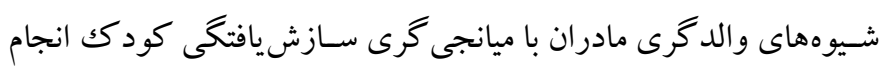

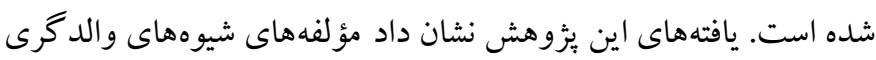

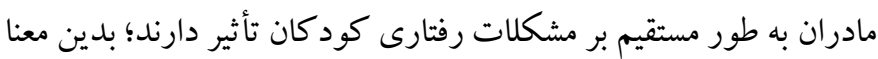

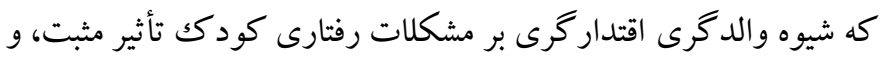

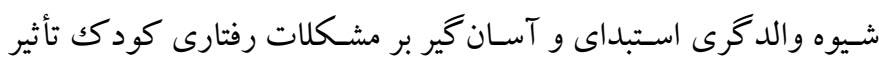

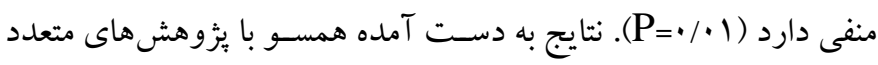

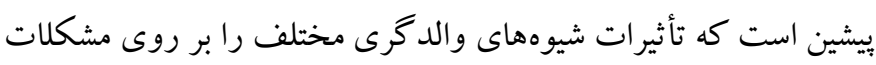

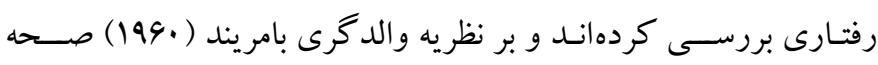

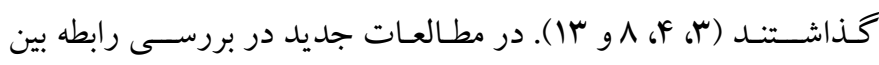
والدگرى و رفتارهاى كود كان، روى مؤلفه هاى رابطه، مراقبت، و ساختار

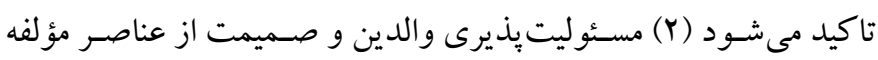

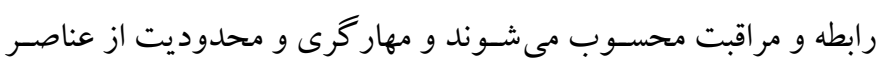

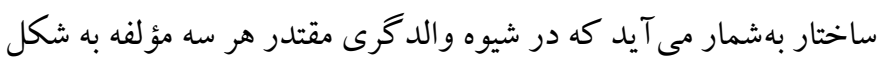

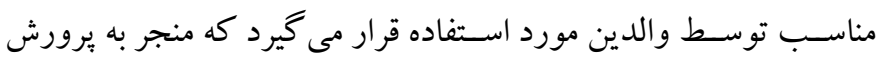

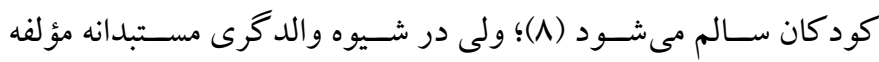

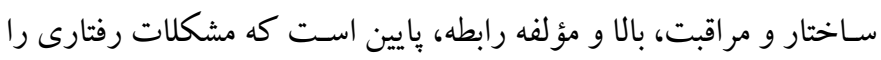

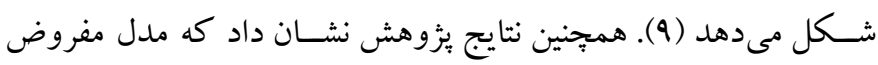

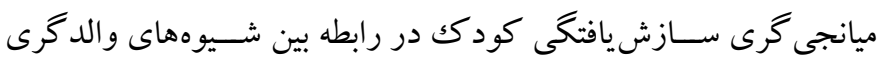
مادران و مشـكلات رفتارى كودكى، برازش قابل قبولى دارد (

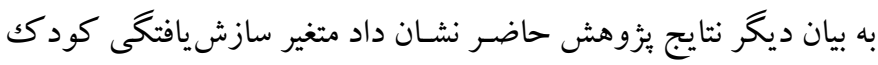
در بيوند دو متغير شيوههاى والدگرى مادران و مشكلات رفتارى كود دكان

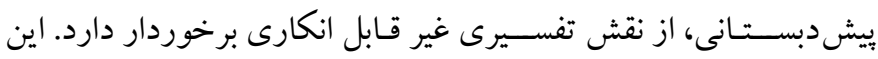

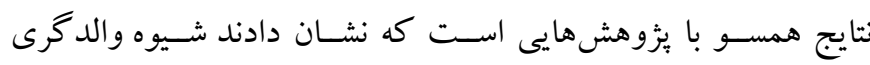

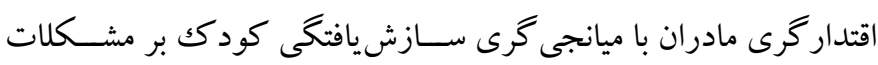

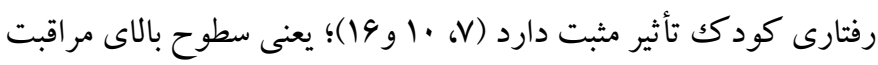
و رفتارهاى مثبت والدينى منجر به سـازش يافتخى بالاتر كود كك در آينده

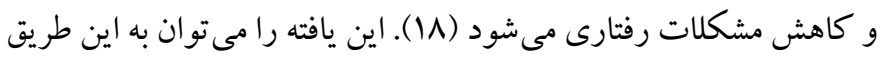

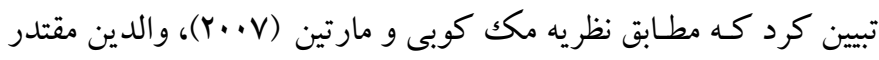

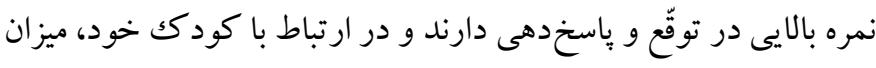

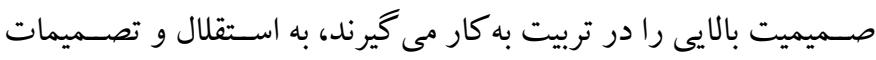


مدارس، همزمان با اهتمام براى سـازش يافتخى كود كان، مى تواند باعث

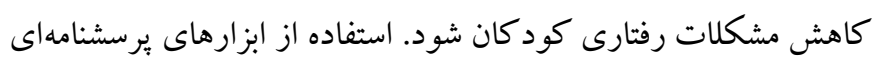

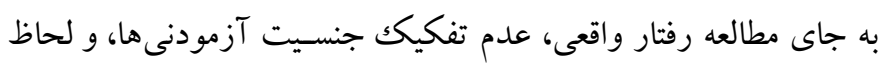

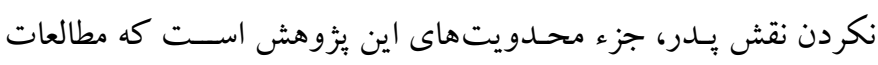

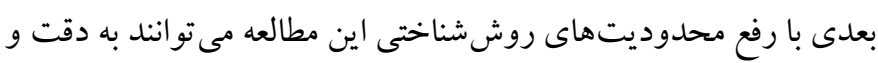
تعميمدهى نتايج بهدست آمده بيفز ايند. تشــكر و قدرانى: اين بُزوهش بركرفته از رســاله دكتراى آقاى محمد كاظم

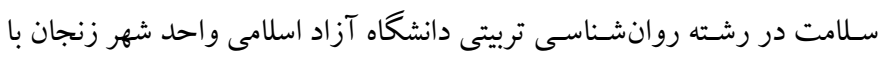

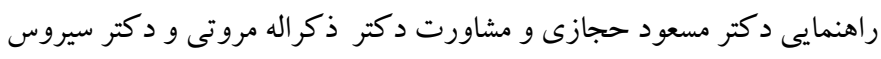

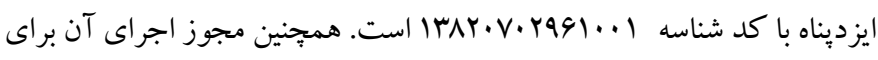

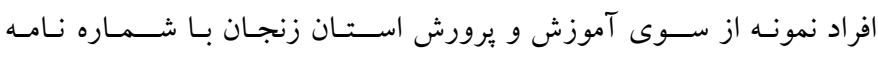

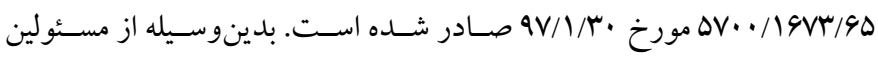

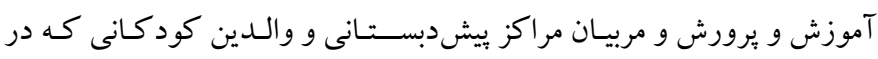
اجراى اين طرح ما را يارى كردند تشكر و قدردانى مى وشئود. تضـاد منافع: ياد آورى مىشـود اين يُزوهش هيج گونه تضـاد منافعى نداشــه

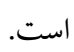

سـاختـار خـانو ادكىى نـابسـامـان را در خانو اده يياده مى كنند و با اعمال تنيدگى روانى زياد بر كود كى، امكان سـازش يافتكى را كاهش مى دئ دهند.

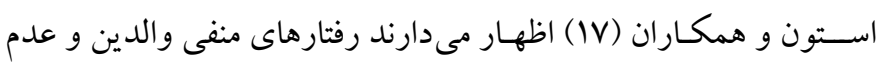

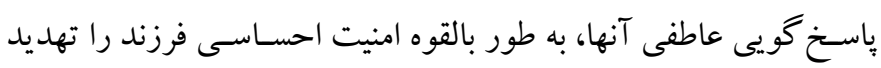

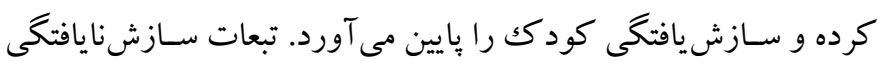
كود كك مى تو اند بهشـكل فقدان خود تنظيمى و احســاســات منفى عليه

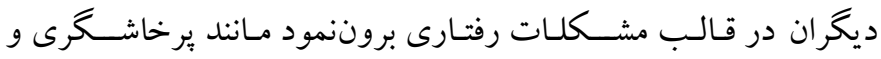

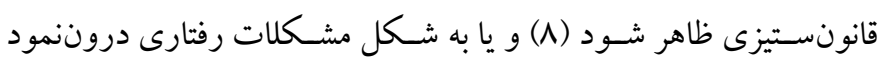

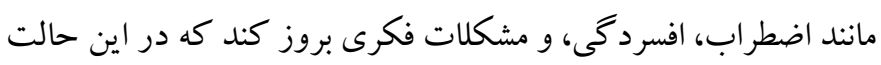
كودك خودتنظيمى بيش از حد سفت و سختى داشته و احساسات منفى خود را به سمت خود سوق مىدهد (Yr). در مجموع نتـايج اين بروهش نشـــان داد كه مؤلفههاى شـــيوههاى

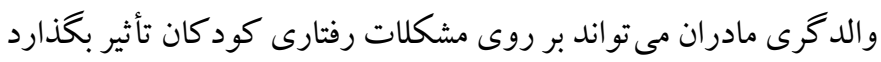

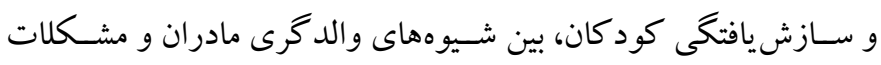

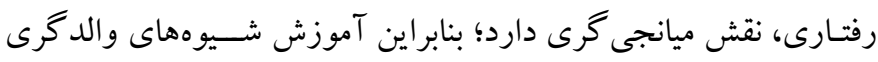

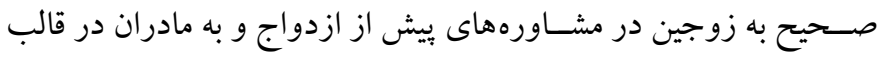

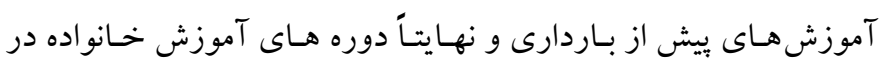




\section{References}

1. Wittig SM, Rodriguez CM. Interaction between maternal and paternal parenting styles with infant temperament in emerging behavior problems. Infant Behavior and Development. 2019 Nov 1; 57:101323. [Link]

2. Zarra-Nezhad M, Aunola K, Kiuru N, Mullola S, Moazami-Goodarzi A. Parenting styles and children's emotional development during the first grade: The moderating role of child temperament. J Psychol Psychother 5: 206. [Link]

3. Parkes A, Green M, Mitchell K. Coparenting and parenting pathways from the couple relationship to children's behavior problems. Journal of Family Psychology. 2019; 33(2): 215-223 [Link]

4. Rosli NA. Effect of Parenting Styles on Children's Emotional and Behavioral Problems Among Different Ethnicities of Muslim Children in the US. Marquette University, Milwaukee, Wisconsin. 2009, pp 39-65. [Link]

5. Fu C, Niu H, Wang M. Parental corporal punishment and children's problem behaviors: The moderating effects of parental inductive reasoning in China. Children and Youth Services Review. 2019; 99(1):19.[Link]

6. Elam KK, Sandler I, Wolchik SA, Tein JY, Rogers A. Latent profiles of post-divorce parenting time, conflict, and quality: Children's adjustment associations. Journal of Family Psychology. 2019; 33(5), 499-510. [Link]

7. Aytac B, Pike A, Bond R. Parenting and child adjustment: a comparison of Turkish and English families. Journal of Family Studies. 2019; 25(3):26786. [Link]

8. Pinquart M. Associations of parenting dimensions and styles with externalizing problems of children and adolescents: an updated meta-analysis. Developmental psychology. 2017;53(5): 845-873. [Link]

9. Hedstrom E. Parenting Style as a Predictor of Internal and External Behavioral Symptoms in Children: The Child's Perspective. 2016, pp 27-55. [Link]

10. Lal K. Impact of family relationship of B.E.D students on their adjustment. American International Journal of Research in Humanities, Arts and Social Sciences. 2013; 5(1): 49-53. [Link]

11. Menaga S, Chandrasekaran V. A study on adjustment of college students. Scholarly research journal for interdisciplinary studies. 2015; 3(16): 2622-2629. [Link]
12. Inguglia, Cristiano, et al. Satisfaction and frustration of autonomy and relatedness needs: Associations with parenting dimensions and psychological functioning. Motivation and Emotion, 2018, 42.5: 691-705. [Link]

13. McKee, L., Colletti, C., Rakow, A., Jones, D. J., \& Forehand, R. (2008). Parenting and child externalizing behaviors: Are the associations specific or diffuse? Aggression and Violent Behavior, 13, 201215. [Link]

14. Nikolaev EL, Baranova EA, Petunova SA. Mental Health Problems in Young Children: The Role of Mothers' Coping and Parenting Styles and Characteristics of Family Functioning. ProcediaSocial and Behavioral Sciences. 2016; 233: 94-99. [Link]

15. Joussemet M, Mageau GA, Larose MP, Briand M, Vitaro F. How to talk so kids will listen \& listen so kids will talk: a randomized controlled trial evaluating the efficacy of the how-to parenting program on children's mental health compared to a wait-list control group. BMC pediatrics. 2018; 18(1): 257. [Link]

16. Barone L, Ozturk Y, Lionetti F. The key role of positive parenting and children's temperament in postinstitutionalized children's socio-emotional adjustment after adoption placement. A RCT study. Social Development. 2019; 28(1): 136-51. [Link]

17. Stone LL, otteen R, Janssens MAM, soenens B, kuntsche E, \& Engles, CRME. Does parental psychological control relate to in ternalizing and externalizing problems in early childhood? An examination using the Berkeley puppet interview. International Behavioral Development. 2013; 37(4): 309-319. [Link]

18. Shigto a, Mangelsdorf SC, \& Brown GL. Roles of Family cohesiveness, material adjustment and child temperament in predicting child behavior with mothers and fathers. Journal of social and Personal Relationships. 2014; 31(2): 200-220. [Link]

19. Soenens B, Vansteenkiste M. A theoretical upgrade of concept of psychological control: Proposing new insights on the basis of self-determination theory. Developmental Review. 2010; 30: 74-79. [Link]

20. Rodríguez-Meirinhos A, Vansteenkiste M, Soenens B, Oliva A, Brenning K, Antolín-Suárez L. When is Parental Monitoring Effective? A Person-centered Analysis of the Role of Autonomy-supportive and Psychologically Controlling Parenting in Referred and Non-Referred Adolescents. Journal of youth and Adolescence. 2019; 29:1-7. [Link] 
21. Joussemet M, Vitaro F, Barker ED, Cote S, Nagin DS, Zoccolillo M, \& Tremblay RE. Controlling parenting and Physica aggression during elementary school. Child Development. 2008; 79: 411-425. [Link]

22. Kaul K, Konantambigi R, \& Anant SJ. Child temperament and emotion socialization by parents and its influence on emotion regulation by children. Journal of Indian Association for Child and Adolescent Mental Health; 2019; 15(2): 13-33. [Link]

23. Putnick DL, Bornstein MH, Lansford JE, Chang L, Deater-Deckard K, DiGiunta L, \& Bombi AS. Agreementin mother and father acceptance-rejection, warmth, and hostility/rejection/neglect of children across nine countries. Cross Cultural Research 2012; 46: 191-223. [Link]

24. Gulay H, onder A. Comparing parental acceptance: the rejection Levels and peer relationship of Turkish preschool children. Procedia Social and Behavioral. 2011; 15: 1818-1823. [Link]

25.Kline RB. Principles and practice of structural equation modeling. Second Edition. New York: The Guilford Press. 2011, pp 20-65. [Link]

26. Rafahi J. Predicting the parenting styles of mothers based on their early patterns and attachment styles. Journal of Women and Society. 1398; 37(10): 196167. [Persian] [Link]
27. Zamany N,Zargar Y,Mehrabizadeh M. The effectiveness of cognitive intervention on improving the executive and self-regulation of children with behavioral problems of extraversion. Health System Research. 2018; 14(4): 467-457. [Persian] [Link]

28. Ahmadi S. The Effect of Music on Adaptation and the Level of Learning of Autistic Children in Isfahan. Scientific Conference of Psychology, Educational Sciences and Pathology of Psychology Society. 2015. [Persian] [Link]

29. Teo T, Noyes J. Explaining the intention to use technology among pre-service teachers: a multi-group analysis of the Unified Theory of Acceptance and Use of Technology. Interactive Learning Environments, 2012, pp 51-66. [Link]

30. Gefen D, Straub DW, \& Boudreau MC. Structural equation modeling and regression: Guidelines for research and practice. Communications of the Association for Information Systems. 2000;4(7), pp 14-61. [Link]

31. Hosokawa R, Katsura T. Role of Parenting Style in Children's Behavioral Problems through the Transition from Preschool to Elementary School According to Gender in Japan. Int $\mathbf{J}$ Environ Res Public Health. 2019;16(1): 21-27. [Link] 